\title{
Flectobacillus lacus sp. nov., isolated from a highly eutrophic pond in Korea
}

Correspondence
Byung C. Cho
bccho@snu.ac.kr
Chung Y. Hwang and Byung C. Cho

School of Earth and Environmental Sciences, Seoul National University, Shillim-dong, Kwanak-gu, Seoul 151-742, Republic of Korea
The genus Flectobacillus was proposed by Larkin et al. (1977). Later, two species ([Flectobacillus] marinus and [Flectobacillus] glomeratus) assigned to the genus Flectobacillus (Borrall \& Larkin, 1978; McGuire et al., 1987) were reclassified as Cyclobacterium marinum (Raj \& Maloy, 1990) and Polaribacter glomeratus (Gosink et al., 1998), respectively. At present, Flectobacillus major is the only accepted Flectobacillus species with a validly published name. The species was first described as 'Microcyclus major' by Gromov (1963) and is the type species of the genus. In this study, we isolated a strain from a highly eutrophic pond and found that the 16S rRNA gene sequence of the isolate was related to those of species of Flectobacillus. Here we describe its phenotypic, physiological and chemotaxonomic features.

In November 2003, a surface freshwater sample was collected, using a sterile tube, from a highly eutrophic pond, Gongdae Pond, located in the campus of Seoul National University. The sample, at ambient temperature, was brought back to the laboratory within $15 \mathrm{~min} ; 10-100 \mu \mathrm{l}$ sample was spread on plates containing R2A agar $[0.05 \%(\mathrm{w} / \mathrm{v})$ yeast extract, $0.05 \%(\mathrm{w} / \mathrm{v})$ peptone, $0.05 \%(\mathrm{w} / \mathrm{v})$ Casamino acids, $0.05 \%$ $(\mathrm{w} / \mathrm{v})$ glucose, $0.05 \%(\mathrm{w} / \mathrm{v})$ starch, $0.03 \%(\mathrm{w} / \mathrm{v})$ sodium pyruvate, $0.03 \%(\mathrm{w} / \mathrm{v}) \mathrm{K}_{2} \mathrm{HPO}_{4}, 0.005 \%(\mathrm{w} / \mathrm{v}) \mathrm{MgSO}_{4}$ and $1.5 \%(\mathrm{w} / \mathrm{v})$ agar, $\mathrm{pH} 7$; Difco] and incubated at $20{ }^{\circ} \mathrm{C}$ for 1 week. Thirteen colonies were randomly selected and subsequently purified four times on $\mathrm{R} 2 \mathrm{~A}$ agar at $20^{\circ} \mathrm{C}$. The

The GenBank/EMBL/DDBJ accession number for the 16S rRNA gene sequence of strain CL-GP79 ${ }^{\top}$ is DQ112352.

Selected phenotypic characteristics of strain CL-GP79 ${ }^{\top}$ and Flectobacillus major DSM $103^{\top}$ are available in a supplementary table in IJSEM Online. isolates were initially characterized on the basis of their 16S rRNA gene sequences. Two of the isolates showed relatively low levels of sequence similarity (94-96\%) to previously described species from different genera: one of these is strain CL-GP79 ${ }^{\mathrm{T}}$, colonies of which are pink on R2A agar. The strain was stored at $-80{ }^{\circ} \mathrm{C}$ in R2A broth (Difco) supplemented with $30 \%(\mathrm{v} / \mathrm{v})$ glycerol until required for further analyses.

The temperature range for growth was tested on the basis of colony formation on R2A plates incubated at temperatures ranging from 5 to $45^{\circ} \mathrm{C}$, using increments of $5^{\circ} \mathrm{C}$. The $\mathrm{pH}$ range ( $\mathrm{pH} 5-10$, using increments of $1 \mathrm{pH}$ unit) for growth was determined by assessing changes in $\mathrm{OD}_{600}$ over the incubation period (up to 7 days) in $\mathrm{R} 2 \mathrm{~A}$ broth. The final $\mathrm{pH}$ was adjusted using $\mathrm{NaOH}$ and $\mathrm{HCl}$ solutions. To test the salt tolerance, R2A agar (Difco) and nutrient agar [0.3\% (w/v) beef extract, $0 \cdot 5 \%(\mathrm{w} / \mathrm{v})$ peptone, $1 \cdot 5 \%(\mathrm{w} / \mathrm{v})$ agar, $\mathrm{pH} 7$; Difco] containing various concentrations of $\mathrm{NaCl}(0,0 \cdot 1$, $0 \cdot 5,1,1 \cdot 5,2,3,5,7 \%, \mathrm{w} / \mathrm{v})$ were used. Growth of the isolate occurred at temperatures between 10 and $35^{\circ} \mathrm{C}$, with optimal growth around $25-30{ }^{\circ} \mathrm{C}$. The isolate did not grow on either R2A agar or nutrient agar supplemented with $0 \cdot 5-7 \%$ (w/v) NaCl. The isolate grew at $\mathrm{pH}$ values from 6 to 9; optimal growth occurred at $\mathrm{pH} 7$.

Morphological and physiological tests were also performed. Gram-staining was performed as described by Smibert \& Krieg (1994). The cellular morphology and the motility of the isolate were observed by phase-contrast microscopy. Transmission electron microscopy (EX2; JEOL) was used to establish whether flagella were present. Anaerobic growth was checked on R2A agar using the GasPak anaerobic system 
(BBL). The pigment absorption spectrum between 200 and $800 \mathrm{~nm}$ was determined by using an Ultraspec 2000 spectrophotometer (Pharmacia Biotech) after ethanol extraction (Gosink et al., 1998). The sample was further alkalized with $0 \cdot 1$ vol. $0 \cdot 1 \mathrm{M} \mathrm{NaOH}$, and the absorption spectrum was obtained again to check for the presence of flexirubin pigments (Gosink et al., 1998). The cells were Gram-negative, aerobic, straight to slightly curved, non-motile rods with no flagella (Fig. 1). Other morphological characteristics are shown in Table 1. Pigment extracts of strain CL-GP79 ${ }^{\mathrm{T}}$ showed an absorption maximum at $477-481 \mathrm{~nm}$ and a spectrum similar to that of F. major DSM $103^{\mathrm{T}}$ (i.e. the maximum absorption peak at $480-482 \mathrm{~nm}$ determined in this study; data not shown). Flexirubin pigments were not detected in either strain.

Catalase and oxidase activities were determined according to the protocols described by Smibert \& Krieg (1994); gelatinase, amylase and nitrate reductase activities and the Voges-Proskauer test were investigated as described by Hansen \& Sørheim (1991). The utilization of organic compounds as sole carbon sources was tested on the basis of colony formation on a minimal medium (Nikitin et al., 2004) to which $\mathrm{NaCl}$ and $\mathrm{CaCl}_{2}$ had not been added. Growth was scored as negative when it was equal to, or less than, that in the negative control (i.e. lacking a carbon source) after incubation at $25^{\circ} \mathrm{C}$ for 1 month. Additional biochemical tests were performed by using API 20NE, API ZYM and API $50 \mathrm{CH}$ strips (bioMérieux) according to the manufacturer's instructions. Sensitivities to antibiotics were assessed using disc-diffusion methodology (Bauer et al., 1966). All phenotypic tests for strain CL-GP79 ${ }^{\mathrm{T}}$ were performed simultaneously with F. major DSM $103^{\mathrm{T}}$ as a reference strain. Strain CL-GP79 ${ }^{\mathrm{T}}$ was positive for catalase, oxidase, gelatinase and

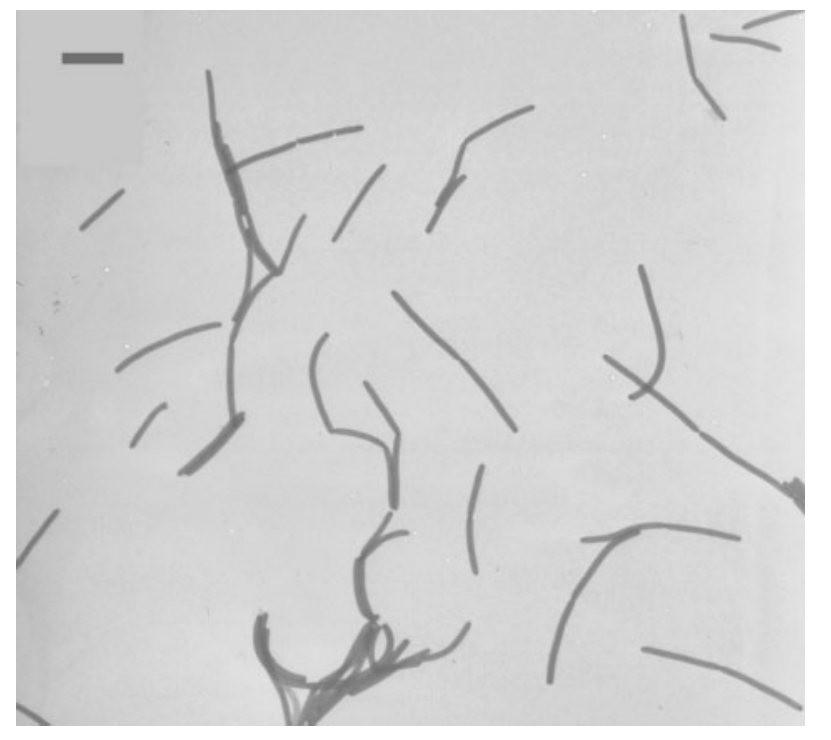

Fig. 1. Transmission electron micrograph of negatively stained cells of strain CL-GP79'. Bar, $5 \mu \mathrm{m}$. amylase, but negative in the Voges-Proskauer test. In the API tests, strain CL-GP79 ${ }^{\mathrm{T}}$ showed a physiological profile that was very similar to that of F. major DSM $103^{\mathrm{T}}$, i.e. they gave the same results for 25 out of 27 tests of enzyme activities, 39 out of 49 tests for acid production, and 8 out of 12 tests for carbon assimilation (Table 1; see also Supplementary Table S1 available in IJSEM Online). Features that differentiated strain CL-GP79 ${ }^{\mathrm{T}}$ from F. major DSM $103^{\mathrm{T}}$ were as follows: acid was produced from D-arabitol and 5-ketogluconate, but not from DL-arabinose, D-xylose, L-rhamnose, amygdalin, arbutin, D-lyxose or L-fucose. Strain CL-GP79 ${ }^{\mathrm{T}}$ assimilated adipate, but did not assimilate L-arabinose, D-mannose, $\mathrm{N}$-acetylglucosamine, D-maltose or gluconate. Strain CL-GP79 ${ }^{\mathrm{T}}$ was not capable of utilizing DL-cysteine or succinate as a sole carbon source. The other results of the biochemical and physiological tests are given in Table 1, Supplementary Table S1 and the species description.

The DNA G + C content of strain CL-GP79 ${ }^{\mathrm{T}}$, determined by HPLC analysis (Mesbah et al., 1989), was $38 \cdot 3 \mathrm{~mol} \%$. This is similar to the values obtained for F. major (39.5$40.3 \mathrm{~mol} \%$; Larkin et al., 1977). The whole-cell fatty acid methyl esters in strains CL-GP79 ${ }^{\mathrm{T}}$ and F. major DSM $103^{\mathrm{T}}$, grown under the same conditions (on R2A plates at $25^{\circ} \mathrm{C}$ for 2 days), were analysed by gas chromatography according to the instructions of the Microbial Identification System (MIDI) at the Korean Culture Center of Microorganisms (Seoul, Korea). The fatty acid composition of strain CL$\mathrm{GP}^{\mathrm{T}}{ }^{\mathrm{T}}$ was similar to that of F. major DSM $103^{\mathrm{T}}$ (Table 2). The major fatty acids of strain CL-GP79 ${ }^{\mathrm{T}}$ were found to be $\mathrm{C}_{16: 1} \omega 5 c$ (mean $\pm \mathrm{SD}, 26 \cdot 9 \pm 10 \cdot 8 \%$ ), iso- $\mathrm{C}_{15: 0} 2-\mathrm{OH}$ and/ or $\mathrm{C}_{16: 1} \omega 7 c(19 \cdot 2 \pm 2 \cdot 3 \%)$ and iso- $\mathrm{C}_{15: 0}(12 \cdot 1 \pm 1 \cdot 3 \%)$. However, a significant amount $(14 \cdot 7 \pm 0 \cdot 1 \%)$ of an unknown fatty acid with a carbon chain length equivalent to $15 \cdot 731$ was found in F. major DSM $103^{\mathrm{T}}$ but not in strain CL-GP79 ${ }^{\mathrm{T}}$ (Table 2). These results support the affiliation of strain CL$\mathrm{GP}^{\mathrm{T}}{ }^{\mathrm{T}}$ to the genus Flectobacillus. It is noteworthy that the fatty acid profile of F. major DSM $103^{\mathrm{T}}$ obtained in this study is quite distinct from that of $F$. major reported by Urakami \& Komagata (1986), possibly because of differences in the cultivation conditions and techniques used.

To establish the phylogenetic relationships within the family Flexibacteraceae, the sequence of the 16S rRNA gene of strain CL-GP79 ${ }^{\mathrm{T}}$ was determined: the $16 \mathrm{~S}$ rRNA gene was PCRamplified from a single colony by using Taq DNA polymerase (Bioneer) and primers 27F and 1492R (Lane, 1991). The PCR product was purified by using the AccuPrep PCR purification kit (Bioneer) and direct sequence determination of the purified 16S rRNA gene was performed with an Applied Biosystems automatic sequencer (ABI3730XL) at Macrogen Corp. (Seoul, Korea). The 16S rRNA gene sequence of strain CL-GP79 ${ }^{\mathrm{T}}$ was compared with $16 \mathrm{~S}$ rRNA gene sequences available in GenBank, using a BLASTN (Altschul et al., 1990) search. The sequence of strain CLGP79 ${ }^{\mathrm{T}}$ was aligned manually with representative sequences of the family Flexibacteraceae obtained from the GenBank 
Table 1. Differential characteristics of Flectobacillus species

Strains: 1, F. lacus CL-GP79 ${ }^{\mathrm{T}}$; 2, F. major DSM $103^{\mathrm{T}}$. Data are from Larkin et al. (1977), Larkin \& Borrall (1984), Raj \& Maloy (1990), Nikitin et al. (1994), Gosink et al. (1998) and this study. Both strains comprise Gram-negative, strictly aerobic, almost straight rods, are non-motile and are able to grow on R2A and nutrient agar containing $0 \%$ or $0.1 \%(\mathrm{w} / \mathrm{v}) \mathrm{NaCl}$, but are unable to grow in the presence of $2-7 \%(\mathrm{w} / \mathrm{v}) \mathrm{NaCl}$. Colonies of both strains are pale pink to rose in colour, round, convex, smooth and entire. +, Positive; -, negative; $\mathrm{W}$, weakly positive; $\mathrm{V}$, variable.

\begin{tabular}{|c|c|c|}
\hline Characteristic & 1 & 2 \\
\hline Habitat & Highly eutrophic pond & Freshwater \\
\hline Colony diameter $(\mathrm{mm})$ & $2-6$ & $4-6$ \\
\hline Cell size (length $\times$ width, $\mu \mathrm{m})$ & $4 \cdot 7-10 \cdot 0 \times 0 \cdot 3-0 \cdot 6$ & $2 \cdot 0-5 \cdot 0 \times 0 \cdot 6-1 \cdot 0$ \\
\hline Temperature range (optimum) $\left({ }^{\circ} \mathrm{C}\right)$ & $10-35(25-30)$ & $4-30(20-30)$ \\
\hline $\mathrm{pH}$ range (optimum) & $6-9(7)$ & $6-8(7)$ \\
\hline \multicolumn{3}{|l|}{ Growth in the presence of $\mathrm{NaCl}$ at: } \\
\hline $0 \cdot 5 \%(\mathrm{w} / \mathrm{v})$ & - & $+^{*}$ \\
\hline $1 \cdot 0 \%(\mathrm{w} / \mathrm{v})$ & - & $+^{*}$ \\
\hline $1 \cdot 5 \%(\mathrm{w} / \mathrm{v})$ & - & $+^{*}$ \\
\hline DNA G + C content $(\mathrm{mol} \%)$ & $38 \cdot 3$ & $39 \cdot 5-40 \cdot 3$ \\
\hline \multicolumn{3}{|l|}{ Biochemical tests } \\
\hline Catalase & + & $\mathrm{W}$ \\
\hline Nitrate reductase & $\mathrm{v} \dagger$ & - \\
\hline$\beta$-Galactosidase & + & $\mathrm{V}$ \\
\hline Urease & - & $\mathrm{V}$ \\
\hline Aesculin hydrolysis & + & $\mathrm{V}$ \\
\hline \multicolumn{3}{|l|}{ Acid production from: } \\
\hline D-Arabinose & - & + \\
\hline L-Arabinose & - & + \\
\hline D-Ribose & - & $\mathrm{V}$ \\
\hline D-Xylose & - & + \\
\hline L-Rhamnose & - & + \\
\hline D-Cellobiose & + & $\mathrm{V}$ \\
\hline \multicolumn{3}{|l|}{ Utilization as a sole carbon source } \\
\hline$N$-Acetylglucosamine & + & - \\
\hline DL-Aspartate & - & $\mathrm{V}$ \\
\hline DL-Cysteine & - & + \\
\hline Ethanol & - & $\mathrm{V}$ \\
\hline Pyruvate & + & $\mathrm{V}$ \\
\hline Succinate & - & + \\
\hline \multicolumn{3}{|l|}{ Antibiotics ( $\mu$ g per disc) $\ddagger$} \\
\hline Kanamycin (30) & $\mathrm{R}$ & S \\
\hline Erythromycin (15) & $\mathrm{R}$ & S \\
\hline Mitomycin (1) & s & $\mathrm{R}$ \\
\hline
\end{tabular}

${ }^{\star}$ Test performed in this study.

$\dagger$ Tested according to Hansen \& Sørheim (1991) in this study and showed a positive response; negative in API 20NE test.

$\ddagger \mathrm{R}$, Resistant; s, susceptible.

and Ribosomal Database Project (Cole et al., 2003) databases, using known 16S rRNA secondary structure information. Phylogenetic trees were obtained by using the neighbourjoining (Saitou \& Nei, 1987), maximum-parsimony (Fitch, 1971) and maximum-likelihood (Felsenstein, 1981) methods. An evolutionary distance matrix for the neighbour-joining method was generated according to the model of Jukes \&
Cantor (1969). The robustness of tree topologies was assessed by using bootstrap analyses based on 1000 replications (for the neighbour-joining and maximum-parsimony methods) or 100 replications (for the maximum-likelihood method). Alignment analysis was carried out using the jPHYDIT program (Jeon et al., 2005) and phylogenetic analyses were carried out using MEGA 3 (Kumar et al., 2004) 
Table 2. Cellular fatty acid compositions (\%) of Flectobacillus species

Strains: 1, F. lacus CL-GP79 ${ }^{\mathrm{T}}$; 2, F. major DSM $103^{\mathrm{T}}$. Both strains were cultured on $\mathrm{R} 2 \mathrm{~A}$ plates at $25^{\circ} \mathrm{C}$ for 2 days. Values are percentages of total fatty acids, expressed as means \pm SD. ECL, Equivalent chain-length; tr, trace amount $(<1 \%)$; -, not detected. Trace amounts of $\mathrm{C}_{17: 0}, \mathrm{C}_{18: 0}, \mathrm{C}_{14: 1} \omega 5 c$, iso- $\mathrm{C}_{17: 0}$, iso- $\mathrm{C}_{17: 1} \omega 9 c$, anteiso- $\mathrm{C}_{17: 0}, \mathrm{C}_{14: 0} 2-\mathrm{OH}, \mathrm{C}_{15: 0} 2-\mathrm{OH}$, iso- $\mathrm{C}_{16: 0} 3-\mathrm{OH}, \mathrm{C}_{17: 0}$ $2-\mathrm{OH}, \mathrm{C}_{13: 0} 3-\mathrm{OH}$ and/or iso- $\mathrm{C}_{15: 1} \mathrm{I}$, ECL 11.543, ECL 13.565 and ECL 16.582 were observed in both strains.

\begin{tabular}{|c|c|c|}
\hline Fatty acid & 1 & 2 \\
\hline $\mathrm{C}_{13: 0}$ & $\operatorname{tr}$ & - \\
\hline $\mathrm{C}_{14: 0}$ & $1 \cdot 7 \pm 0 \cdot 2$ & $1 \cdot 0 \pm 0 \cdot 01$ \\
\hline $\mathrm{C}_{15: 0}$ & $4 \cdot 3 \pm 0 \cdot 3$ & $\operatorname{tr}$ \\
\hline $\mathrm{C}_{16: 0}$ & $1 \cdot 3 \pm 0 \cdot 2$ & $1 \cdot 0 \pm 0 \cdot 3$ \\
\hline $\mathrm{C}_{20: 0}$ & - & $\operatorname{tr}$ \\
\hline $\mathrm{C}_{15: 1} \omega 6 c$ & $4 \cdot 2 \pm 1 \cdot 7$ & $\operatorname{tr}$ \\
\hline $\mathrm{C}_{15: 1} \omega 8 c$ & - & $\operatorname{tr}$ \\
\hline $\mathrm{C}_{16: 1} \omega 5 c$ & $26 \cdot 9 \pm 10 \cdot 8$ & $36 \cdot 4 \pm 1 \cdot 1$ \\
\hline $\mathrm{C}_{17: 1} \omega 6 c$ & $1 \cdot 5 \pm 0 \cdot 9$ & $\operatorname{tr}$ \\
\hline $\mathrm{C}_{17: 1} \omega 8 c$ & $\operatorname{tr}$ & - \\
\hline $\mathrm{C}_{18: 1} \omega 5 c$ & - & $\operatorname{tr}$ \\
\hline $\mathrm{C}_{18: 1} \omega 9 c$ & $\operatorname{tr}$ & - \\
\hline iso- $\mathrm{C}_{13: 0}$ & $\operatorname{tr}$ & - \\
\hline anteiso- $\mathrm{C}_{13: 0}$ & $\operatorname{tr}$ & - \\
\hline iso- $\mathrm{C}_{15: 0}$ & $12 \cdot 1 \pm 1 \cdot 3$ & $9 \cdot 5 \pm 0 \cdot 8$ \\
\hline anteiso- $\mathrm{C}_{15: 0}$ & $2 \cdot 4 \pm 0 \cdot 2$ & $2 \cdot 5 \pm 0 \cdot 4$ \\
\hline iso- $\mathrm{C}_{16: 0}$ & - & $\operatorname{tr}$ \\
\hline iso- $\mathrm{C}_{14: 0} 3-\mathrm{OH}$ & - & $\operatorname{tr}$ \\
\hline $\mathrm{C}_{15: 0} 3-\mathrm{OH}$ & $3 \cdot 5 \pm 1 \cdot 3$ & - \\
\hline iso- $\mathrm{C}_{15: 0} 3-\mathrm{OH}$ & $3 \cdot 8 \pm 5 \cdot 3$ & $3 \cdot 7 \pm 0 \cdot 2$ \\
\hline $\mathrm{C}_{16: 0} 2-\mathrm{OH}$ & - & $\operatorname{tr}$ \\
\hline $\mathrm{C}_{16: 0} 3-\mathrm{OH}$ & $2 \cdot 9 \pm 0 \cdot 5$ & $2 \cdot 9 \pm 0 \cdot 4$ \\
\hline $\mathrm{C}_{17: 0} 3-\mathrm{OH}$ & $\operatorname{tr}$ & - \\
\hline iso- $\mathrm{C}_{17: 0} 3-\mathrm{OH}$ & $3 \cdot 6 \pm 0 \cdot 01$ & $4 \cdot 6 \pm 0 \cdot 8$ \\
\hline $\mathrm{C}_{14: 0} 3-\mathrm{OH}$ and/or iso- $\mathrm{C}_{16: 1} \mathrm{I}$ & $1 \cdot 4 \pm 0 \cdot 4$ & $\operatorname{tr}$ \\
\hline iso- $\mathrm{C}_{15: 0} 2-\mathrm{OH}$ and/or $\mathrm{C}_{16: 1} \omega 7 c$ & $19 \cdot 2 \pm 2 \cdot 3$ & $10 \cdot 8 \pm 1 \cdot 2$ \\
\hline anteiso- $\mathrm{C}_{17: 1} \mathrm{~B}$ and/or iso- $\mathrm{C}_{17: 1} \mathrm{I}$ & $\operatorname{tr}$ & $2 \cdot 5 \pm 0 \cdot 1$ \\
\hline ECL $14 \cdot 959$ & $5 \cdot 0 \pm 0 \cdot 03$ & $1 \cdot 6 \pm 0 \cdot 4$ \\
\hline ECL $15 \cdot 731$ & - & $14 \cdot 7 \pm 0 \cdot 1$ \\
\hline
\end{tabular}

and PAUP* 4.0 (Swofford, 1998). Likelihood parameters were estimated by using the hierarchical ratio tests in MODELTEST, version 3.04 (Posada \& Crandall, 1998). An almost complete 16S rRNA gene sequence of strain CL$\mathrm{GP79}^{\mathrm{T}}(1369 \mathrm{bp})$ was obtained. Strain CL-GP79 ${ }^{\mathrm{T}}$ was closely related to F. major ( $95 \cdot 7 \%$ similarity). The tree topologies inferred from the three tree-making algorithms showed that strain CL-GP79 ${ }^{\mathrm{T}}$ formed a robust cluster with species of the genus Flectobacillus (Fig. 2). This grouping was supported by high bootstrap values (neighbour-joining and maximumlikelihood methods, $100 \%$; maximum-parsimony method, $98 \%)$. Thus, it is clear that our isolate belongs to the genus Flectobacillus. However, the relatively low level of similarity $(95 \cdot 7 \%)$ between the $16 \mathrm{~S}$ rRNA gene sequences of strain

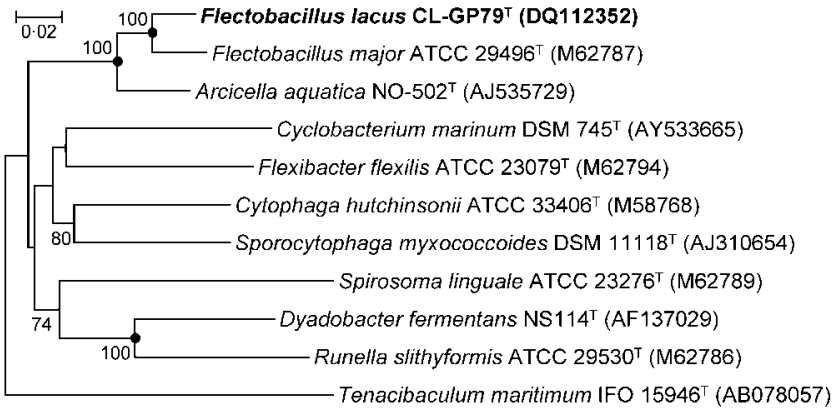

Fig. 2. Neighbour-joining tree based on 16S rRNA gene sequences showing the relationship between $F$. lacus CLGP79 $^{\top}$ and other related genera belonging to the Flexibacteraceae. Only those bootstrap values (expressed as percentages of 1000 replications) above $70 \%$ are shown at nodes. Filled circles indicate that the corresponding nodes were also recovered in maximum-likelihood and maximum-parsimony trees. Bar, 0.02 nucleotide substitutions per site.

CL-GP79 ${ }^{\mathrm{T}}$ and F. major ATCC $29496^{\mathrm{T}}$ indicated that strain CL-GP79 ${ }^{\mathrm{T}}$ represents a novel species in the genus (Stackebrandt \& Goebel, 1994; Rosselló-Mora \& Amann, 2001).

Phylogenetic analyses based on 16S rRNA gene sequences, chemotaxonomic data and physiological features suggest that strain CL-GP79 ${ }^{\mathrm{T}}$ belongs to the genus Flectobacillus and represents a novel species of the genus. Therefore, strain CL-GP79 ${ }^{\mathrm{T}}$ should be assigned to a novel species of the genus Flectobacillus, for which the name Flectobacillus lacus sp. nov. is proposed.

\section{Description of Flectobacillus lacus sp. nov.}

Flectobacillus lacus (la'cus. L. gen. n. lacus of a lake or pond, referring to the isolation of the type strain).

Gram-negative, aerobic, almost straight rods, approximately $0 \cdot 3-0 \cdot 6 \mu \mathrm{m}$ wide and $4 \cdot 7-10 \cdot 0 \mu \mathrm{m}$ long. Cells are nonmotile and do not possess flagella. Colonies on R2A agar are pale pink to rose in colour and are round $(2-6 \mathrm{~mm}$ in diameter), convex and smooth with entire margins. Growth occurs at $10-35^{\circ} \mathrm{C}$ and $\mathrm{pH} 6-9$; optimal temperature and $\mathrm{pH}$ for growth are $25-30^{\circ} \mathrm{C}$ and $\mathrm{pH} 7$, respectively. Grows well on R2A and nutrient agar without $\mathrm{NaCl}$ or with $0.1 \%$ $(\mathrm{w} / \mathrm{v}) \mathrm{NaCl}$; no growth occurs in the presence of $\geqslant 0.5 \%$ (w/v) NaCl. Grows on R2A medium and nutrient medium, but not on MacConkey medium. Flexirubin pigments are absent. Positive for catalase, oxidase, gelatinase and amylase activities; negative in the Voges-Proskauer test. Positive for $\alpha$-galactosidase, $\beta$-galactosidase, aesculin hydrolysis, alkaline phosphatase, acid phosphatase, esterase (C4), esterase lipase (C8), leucine, valine and cystine arylamidases, trypsin, $\alpha$-chymotrypsin, naphthol-phosphohydrolase, $\alpha$-glucosidase, $\beta$-glucosidase, $N$-acetyl- $\beta$-glucosaminidase, $\alpha$-mannosidase and $\alpha$-fucosidase. Negative for indole 
production, arginine dihydrolase, lipase $(\mathrm{C} 14)$ and $\beta$ glucuronidase. Other phenotypic properties (e.g. acid production, utilization of carbon, sensitivity to antibiotics) are shown in Table 1 and Supplementary Table S1. The DNA G $+\mathrm{C}$ content is $38 \cdot 3 \mathrm{~mol} \%$. The major fatty acids are $\mathrm{C}_{16: 1} \omega 5 c$ (mean $\pm \mathrm{SD}, 26 \cdot 9 \pm 10 \cdot 8 \%$ ), iso- $\mathrm{C}_{15: 0} 2-\mathrm{OH}$ and $/$ or $\mathrm{C}_{16: 1} \omega 7 c(19 \cdot 2 \pm 2 \cdot 3 \%)$ and iso- $\mathrm{C}_{15: 0}(12 \cdot 1 \pm 1 \cdot 3 \%)$.

The type strain, CL-GP79 ${ }^{\mathrm{T}}\left(=\mathrm{KCCM} \quad 42271^{\mathrm{T}}=\mathrm{JCM}\right.$ $\left.13398^{\mathrm{T}}\right)$, was isolated from a highly eutrophic pond, Gongdae Pond, located in the campus of Seoul National University, Korea.

\section{Acknowledgements}

We acknowledge the expert technical support of Ms M. J. Kang in electron microscopy carried out at the National Center for Interuniversity Research Facilities at Seoul National University. This work was supported (in part) by the BK21 project of the Korean Government.

\section{References}

Altschul, S. F., Gish, W., Miller, W., Myers, E. W. \& Lipman, D. J. (1990). Basic local alignment search tool. J Mol Biol 215, 403-410.

Bauer, A. W., Kirby, W. M. M., Sherris, J. C. \& Turck, M. (1966). Antibiotic susceptibility testing by a standardized single disk method. Am J Clin Pathol 45, 493-496.

Borrall, R. \& Larkin, J. M. (1978). Flectobacillus marinus (Raj) comb. nov., a marine bacterium previously assigned to Microcyclus. Int J Syst Bacteriol 28, 341-343.

Cole, J. R., Chai, B., Marsh, T. L. \& 8 other authors (2003). The Ribosomal Database Project (RDP-II): previewing a new autoaligner that allows regular updates and the new prokaryotic taxonomy. Nucleic Acids Res 31, 442-443.

Felsenstein, J. (1981). Evolutionary trees from DNA sequences: a maximum likelihood approach. J Mol Evol 17, 368-376.

Fitch, W. M. (1971). Toward defining the course of evolution: minimum change for a specific tree topology. Syst Zool 20, 406-416.

Gosink, J. J., Woese, C. R. \& Staley, J. T. (1998). Polaribacter gen. nov., with three new species, $P$. irgensii sp. nov., P. franzmannii sp. nov. and $P$. filamentus sp. nov., gas vacuolate polar marine bacteria of the Cytophaga-Flavobacterium-Bacteroides group and reclassification of 'Flectobacillus glomeratus' as Polaribacter glomeratus comb. nov. Int J Syst Bacteriol 48, 223-235.

Gromov, B. V. (1963). A new bacterium of the genus Microcyclus. Dokl Akad Nauk SSSR 152, 733-734 (in Russian).

Hansen, G. H. \& Sørheim, R. (1991). Improved method for phenotypical characterization of marine bacteria. J Microbiol Methods 13, 231-241.

Jeon, Y. S., Chung, H., Park, S., Hur, I., Lee, J. H. \& Chun, J. (2005). jPHYDIT: a JAVA-based integrated environment for molecular phylogeny of ribosomal RNA sequences. Bioinformatics 21, 3171-3173.
Jukes, T. H. \& Cantor, C. R. (1969). Evolution of protein molecules. In Mammalian Protein Metabolism, pp. 21-132. Edited by H. N. Munro. New York: Academic Press.

Kumar, S., Tamura, K. \& Nei, M. (2004). MEGA 3: integrated software for molecular evolutionary genetics analysis and sequence alignment. Brief Bioinform 5, 150-163.

Lane, D. J. (1991). 16S/23S rRNA sequencing. In Nucleic Acid Techniques in Bacterial Systematics, pp. 115-175. Edited by E. Stackebrandt \& M. Goodfellow. Chichester: Wiley.

Larkin, J. M. \& Borrall, R. (1984). Genus III. Flectobacillus Larkin, Williams and Taylor 1977, 152 ${ }^{\mathrm{AL}}$. In Bergey's Manual of Systematic Bacteriology, vol. 1, pp. 129-132. Edited by N. R. Krieg \& J. G. Holt. Baltimore: Williams \& Wilkins.

Larkin, J. M., Williams, P. M. \& Taylor, R. (1977). Taxonomy of the genus Microcyclus Ørskov 1928: reintroduction and emendation of the genus Spirosoma Migula 1894 and proposal of a new genus, Flectobacillus. Int J Syst Bacteriol 27, 147-156.

McGuire, A. J., Franzmann, P. D. \& McMeekin, T. A. (1987). Flectobacillus glomeratus sp. nov., a curved, nonmotile, pigmented bacterium isolated from antarctic marine environments. Syst Appl Microbiol 9, 265-272.

Mesbah, M., Premachandran, U. \& Whitman, W. B. (1989). Precise measurement of the $\mathrm{G}+\mathrm{C}$ content of deoxyribonucleic acid by highperformance liquid chromatography. Int J Syst Bacteriol 39, 159-167.

Nikitin, D. I., Oranskaya, M. S., Pitryuk, I. A., Chernykh, N. A. \& Lysenko, A. M. (1994). A new ring-forming bacterium Arcocella aquatica gen. et sp. nov. Mikrobiologiia 63, 152-159 (in Russian).

Nikitin, D. I., Strömpl, C., Oranskaya, M. S. \& Abraham, W.-R. (2004). Phylogeny of the ring-forming bacterium Arcicella aquatica gen. nov., sp. nov. (ex Nikitin et al. 1994), from a freshwater neuston biofilm. Int J Syst Evol Microbiol 54, 681-684.

Posada, D. \& Crandall, K. A. (1998). MODELTEST: testing the model of DNA substitution. Bioinformatics 14, 817-818.

Raj, H. D. \& Maloy, S. R. (1990). Proposal of Cyclobacterium marinus gen. nov., comb. nov., for a marine bacterium previously assigned to the genus Flectobacillus. Int J Syst Bacteriol 40, 337-347.

Rossello-Mora, R. \& Amann, R. (2001). The species concept for prokaryotes. FEMS Microbiol Rev 25, 39-67.

Saitou, N. \& Nei, M. (1987). The neighbor-joining method: a new method for reconstructing phylogenetic trees. Mol Biol Evol 4, 406-425.

Smibert, R. M. \& Krieg, N. R. (1994). Phenotypic characterization. In Methods for General and Molecular Bacteriology, pp. 607-654. Edited by P. Gerhardt, R. G. E. Murray, W. A. Wood \& N. R. Krieg. Washington, DC: American Society for Microbiology.

Stackebrandt, E. \& Goebel, B. M. (1994). Taxonomic note: a place for DNA-DNA reassociation and 16S rRNA sequence analysis in the present species definition in bacteriology. Int J Syst Bacteriol 44, 846-849.

Swofford, D. L. (1998). PAUP ${ }^{\star}$ - Phylogenetic Analysis Using Parsimony, version 4. Sunderland, MA: Sinauer.

Urakami, T. \& Komagata, K. (1986). Methanol-utilizing Ancylobacter strains and comparison of their cellular fatty acid compositions and quinone systems with those of Spirosoma, Flectobacillus, and Runella species. Int J Syst Bacteriol 36, 415-421. 